\title{
Characterization of pain resulting from perineal trauma in women with vaginal delivery
}

\author{
Caracterização da dor decorrente de traumas perineais em mulheres com parto vaginal
}

Anayhan Marques Nascimento Silva ${ }^{1}$, Luciano Marques dos Santos ${ }^{1}$, Erika Anny Costa Cerqueira ${ }^{1}$, Evanilda Souza de Santana Carvalho $^{1}$, Aline Silva Gomes Xavier ${ }^{1}$

DOI 10.5935/2595-0118.20180030

\section{ABSTRACT}

BACKGROUND AND OBJECTIVES: Perineal pain in the puerperium of women with perineal traumas can affect the quality of life and interfere with normal activities and physiological needs. In addition, many obstetric practitioners neglect this symptom and an incipient scientific production about the characterization of this pain is observed. Therefore, this study aimed to compare the characteristics of perineal pain in women with perineal traumas due to episiotomy and laceration, according to the Brazilian Version of the McGill Pain Questionnaire, in a public maternity hospital in the interior of Bahia.

METHODS: A cross-sectional study was carried out with 499 postpartum women who had a vaginal delivery and who presented with perineal pain associated with local traumas.

RESULTS: The characterization of perineal pain was the same for both traumas, being described as "that jerk", "boring" and "uncomfortable".

CONCLUSION: Perineal pain has considerable intensity and causes discomfort in women. Therefore, it is important that the episiotomy is performed in a restricted way and that the professionals seek to use techniques of perineal protection, as this will reduce the frequency of perineal pain and provide greater comfort to the woman in the immediate puerperium.

Keywords: Episiotomy, Perineal pain, Perineum.

1. Universidade Estadual de Feira de Santana, Feira de Santana, BA, Brasil.

Submitted in December 29, 2017.

Accepted for publication in April 27, 2018.

Conflict of interests: none - Sponsoring sources: none.

Correspondence to:

Av. Transnordestina, s/n - Novo Horizonte

44036-900 Feira de Santana, BA, Brasil.

E-mail: anny_c@live.com

(c) Sociedade Brasileira para o Estudo da Dor
RESUMO

JUSTIFICATIVA E OBJETIVOS: A dor perineal no puerpério de mulheres com traumas perineais pode afetar a qualidade de vida e interferir nas atividades habituais e necessidades fisiológicas. Além disso, muitos profissionais da prática obstétrica negligenciam esse sintoma e observa-se uma incipiente produção científica acerca da caracterização dessa dor. Sendo assim, este estudo teve o objetivo de comparar as características da dor perineal em mulheres com traumas perineais decorrentes de episiotomia e laceraçáo, conforme dimensóes da Versão Brasileira do Questionário de dor de McGill, em uma maternidade pública do interior da Bahia. MÉTODOS: Estudo transversal realizado com 499 puérperas que tiveram parto vaginal e que apresentaram dor perineal associada a traumas locais.

RESULTADOS: A caracterizaçáo da dor perineal foi igual para ambos os traumas, sendo descrita como "que repuxa", "chata" e "incômoda".

CONCLUSÁO: A dor perineal possui intensidade considerável e causa desconforto nas mulheres. Sendo assim, é importante que a episiotomia seja realizada de forma restrita e que os profissionais procurem utilizar técnicas de proteçâo perineal, pois, dessa forma, reduzirá a frequência de dor perineal e proporcionará maior conforto à mulher no puerpério imediato.

Descritores: Dor perineal, Episiotomia, Períneo.

\section{INTRODUCTION}

Routine procedures, which are sometimes unnecessary and with no scientific basis, have been used in national healthcare establishments ${ }^{1}$. Among the clinical consequences resulting from interventions during parturient care, besides stress and suffering, there are perineal traumas, which may be spontaneous or provoked.

Perineal trauma occurrence is frequent after normal labor ${ }^{2}$. Spontaneous traumas consist of lacerations, which may occur during the newborn passage through the birth canal. Surgical or provoked traumas, in turn, are the episiotomies, which are incisions made in the perineum. The "Nascer no Brasil" survey (Born in Brazil) showed that $56 \%$ of women with low obstetric risk were submitted to episiotomy, and this procedure was more frequent among primiparous women and women in the Mid-West region ${ }^{1}$.

In both perineal traumas, affected women are exposed in the puerperium to morbidities and some signs and symptoms, such as perineal pain $^{3,4}$, dyspareunia ${ }^{3,5}$, bleeding, infections, edema, bruising, which may compromise some of their usual activities 
and physiological needs, bringing them considerable discomfort and affecting the quality of life in the postpartum period.

It is observed in the obstetric practice a concern with pain during childbirth and post-cesarean section. However, perineal pain in the puerperium due to traumas in this region is often overlooked or ignored by assistant professionals, who neglect caring for the mother in the detriment of neonatal care. Such event can affect the woman's quality of life immediately after delivery, since pain interferes, for example, in her mobility, in the ability to lie down ${ }^{6}$ and sleep ${ }^{6,7}$.

Although the perineal pain evaluation and its characteristics in women with traumas due to vaginal delivery are not a constant in the healthcare workers clinical practice, this conduct is necessary to analyze this problem more precisely and, consequently, to assist in providing to postpartum women qualified attention. The McGill questionnaire is considered one of the most comprehensive instruments to assess pain in the sensory-discriminative, affective-motivational and cognitive-evaluative dimensions, where the individual points out the characteristics of the pain experienced. Sensory-discriminative dimension is primarily influenced by the fast conduction spinal systems; the motivational-affective dimension is processed by the reticular formation structures of the brainstem and limbic, which are influenced by nociceptive systems of slow spinal conduction. Neocortical units compare nociceptive information with experiences and exercise control over the structures responsible for the sensory-discriminative and affective-motivational dimensions ${ }^{8}$.

Each pain dimension in the McGill questionnaire presents categories, which, in turn, have descriptors. It is known that in order to consider a descriptor of the Brazilian Version of the McGill Pain Questionnaire (Br-MPQ) as a pain characteristic, it should be mentioned by at least $33 \%$ of the people surveyed ${ }^{9}$. Thus, only the descriptors with frequencies above this value are considered pain characteristics.

In a survey about the production of knowledge, both internationally and nationally, on the characterization of pain associated with perineal trauma, few studies were found. Thus, the question is what are the characteristics of perineal pain presented by women with perineal sutures due to episiotomies or spontaneous laceration?

In this sense, this study aimed to compare the perineal pain characteristics in women with perineal traumas due to episiotomy or laceration, according to the $\mathrm{Br}-\mathrm{MPQ}$ dimensions, in a public maternity hospital in the interior of Bahia.

\section{METHODS}

A descriptive, cross-sectional study conducted in a rooming-in setting for women in post-vaginal delivery.

The simple random sample was estimated in 306 postpartum women with pain, considering an error margin of five percentage points and a $95 \%$ confidence level in a population of 1,500 deliveries, expecting to find $52 \%$ of pain frequency ${ }^{6}$, being $20 \%$ added for losses. However, the final sample consisted of 449 postpartum women who presented perineal pain due to local traumas from September 2013 to December 2014.
For inclusion in the study, the following criteria were used: to be postpartum of normal and vertex delivery who presented some perineal lesion due to the parturition process, to have adequate psychic, clinical and obstetric conditions to answer the questions and to be more than six hours postpartum.

The structured interview technique was used, and a form was applied with sociodemographic, obstetric, perinatal questions and about the perineal condition. For pain characterization, the third part of Br-MPQ was used, which consists of 68 words divided into 4 categories: sensory (10 subcategories), affective (5 subcategories), evaluation (01 subcategory) and mixed (04 subcategories). Each subcategory consists of 2 to 6 descriptors, and each participant could choose only one or no descriptors.

The study followed the formal requirements of national and international standards for research involving human beings. Among the other rules followed were the presentation of the objectives, data collection techniques, benefits and harms, among other information. The subjects who accepted to participate in the study signed of the Free and Informed Consent Form (FICT).

The research project was appreciated by the Research Ethics Committee of the State University of Feira de Santana and was approved under the number 69/2012.

\section{Statistical analysis}

For the data analysis, the descriptive statistics was used by calculating the absolute and relative frequencies. Data were analyzed using the Statistical Package for the Social Sciences (SPSS), version 22.0.

\section{RESULTS}

Among the 499 postpartum women who participated in the study, $51.9 \%$ had an episiotomy, and $48.1 \%$ had a perineal laceration. Most of the women who had an episiotomy were young women up to 20 years old (48.6\%), completed high school (34.7\%) and self-reported as brown (54.4\%). $78.4 \%$ were primiparous, $98.5 \%$ attended prenatal visits, and of these, $67.2 \%$ attended 6 or more prenatal visits. Women presenting perineal laceration were mostly between 21 and 30 years old (44.2\%), completed high school (40.4\%) and self-reported as brown (54.2\%). 47.1\% were primiparous, and $99.2 \%$ reported having attended prenatal care, $66.3 \%$ of whom attended 6 or more visits.

Among women with episiotomy, $60.2 \%$ received oxytocin, and $57.1 \%$ remained hospitalized for up to 5 hours in labor. Medical professionals performed $88.4 \%$ of deliveries, and $98.1 \%$ of women gave birth in the horizontal position. Among the postpartum women who presented laceration, $60.4 \%$ used oxytocin, and $63.8 \%$ remained up to 5 hours hospitalized at the Obstetric Center; $70 \%$ of the deliveries were performed by a physician, and $91.7 \%$ were in the horizontal position.

Regarding the characterization of pain according to the Br-MPQ dimensions, the sensory-discriminative was the most chosen among the women with episiotomy and laceration, reaching a percentage between $59.4 \%$ and $60.4 \%$, respectively, followed by the motivational-affective dimension for both traumas ( $18 \%$ and $17.4 \%$, respectively). 
The most used categories in the sensory-discriminative dimension for women with episiotomy were the temporal, marked by more than half of the women $(63.3 \%)$, followed by the general $(61.8 \%)$ and point pressure (45.6\%). In women who suffered laceration, the most chosen categories were temporal (61.7\%), general $(57.5 \%)$ and traction $(37.9 \%)$.

In the motivational-affective dimension, the displeasure category was the most reported by women with perineal pain due to an episiotomy (55.2\%), and $47.9 \%$ of women with laceration also chose this category. The cognitive-evaluative dimension is composed of only one category, subjective evaluation, and this was chosen by $74.5 \%$ of the women with episiotomy and $68.3 \%$ of those who suffered laceration. In the mixed dimension, in turn, the sensory category was the most reported among women in both groups, $21.2 \%$ among women with episiotomy and $17.9 \%$ among those with a laceration.

According to table 1, the most used descriptors of sensory-discriminative dimension for women with episiotomy were: "that comes and goes" (27.4\%) from the temporal category; "jumping from here and there" (8.1\%) from the spatial category; "pricks like a needle" (31.7\%) from the point pressure category; "cuts like a razor" (10.4\%) from the incision category; "like a pinch" (20.1\%) from the compression category; "that stretches" (42.1\%) from the traction category; "that heats" (18.1\%) from the heat category; "burnt" $(21.2 \%)$ from the vivacity category; "dampened" $(5.4 \%)$ from the deafness category, "sensitive" (22.8\%) from the general category.

Women with perineal laceration defined pain in this dimension, predominantly as "that comes and goes" (32.5\%) from the temporal category; "jumping from here and there" $(4.6 \%)$ from the spatial category; "pricks like a needle" (27.1\%) from the point pressure category; "cutting like a razor" (4.2\%) and "tearing the flesh" (4.2\%) from the incision category; "like a pinch" (17.5\%) from the compression category; "that stretches" (37.1\%) from the traction category; "that heats" $(12.1 \%)$ from the heat category; "burnt" (24.2\%) from the vivacity category; "dampened" (3.8\%) from the deafness category and "sensitive" (23.3\%) from the general category (Table 1).

According to table 2, the most referred motivational-affective descriptors for women submitted to episiotomy were "tiring" (9.3\%), "of cold sweating" (5.4\%), "horrible" (6.8\%), "punishing" (13.5\%) and "boring" (39.8\%), of fatigue, autonomy, fear, punishment, displeasure categories, respectively. Following this same categories orders, most of the women with laceration reported more frequently the descriptors "tiring" (9.6\%), "of cold sweating" (3.3\%), "horrible" (3.8\%), "punishing" (5.4\%) and "boring" (37.1\%).

In the cognitive-evaluative dimension, the "uncomfortable" descriptor obtained frequencies between 37.6 and $33.3 \%$ among postpartum women with episiotomy and laceration, respectively, while the "mild" descriptor obtained frequencies of 31.7 and 30\% (Table 3).

Regarding the mixed dimension descriptors, women with episiotomies reported more frequently as "that holds" (6.2\%) in pain/ movement category; "that grows and decreases" (11.2\%) in sensory category; "cold" ( $9.7 \%)$ in cold category and "that makes me tense" $(10.1 \%)$ in emotional category. In pain/movement category, wom-
Table 1. Perineal pain characterization according to sensorial-discriminative dimension's descriptors of the pain questionnaire (Br-MPQ) in women in vaginal postpartum with perineal trauma

\begin{tabular}{|c|c|c|}
\hline $\begin{array}{l}\text { Descriptors of } \\
\text { sensory-discriminative dimension }\end{array}$ & $\begin{array}{l}\text { Episiotomy } \\
n=259(\%)\end{array}$ & $\begin{array}{l}\text { Laceration } \\
\mathrm{n}=240(\%)\end{array}$ \\
\hline $\begin{array}{l}\text { Temporal } \\
\text { That comes and goes } \\
\text { Pulsing } \\
\text { Throbbing } \\
\text { In blows } \\
\text { Not chosen }\end{array}$ & $\begin{array}{l}71(27.4) \\
20(7.7) \\
68(26.3) \\
5(1.9) \\
95(36.7)\end{array}$ & $\begin{array}{c}78(32.5) \\
12(5) \\
56(23.3) \\
2(0.8) \\
92(38.4)\end{array}$ \\
\hline $\begin{array}{l}\text { Spatial } \\
\text { Jumping from here and there } \\
\text { That spreads in circles } \\
\text { Radiating } \\
\text { Not chosen }\end{array}$ & $\begin{array}{c}21(8.1) \\
8(3.1) \\
17(6.6) \\
213(82.2)\end{array}$ & $\begin{array}{c}11(4.6) \\
4(1.7) \\
9(3.8) \\
216(90)\end{array}$ \\
\hline $\begin{array}{l}\text { Point pressure } \\
\text { Pricks like a needle } \\
\text { It's like a stabbing } \\
\text { Like knifepoint } \\
\text { Drill like a drilling machine } \\
\text { Not chosen }\end{array}$ & $\begin{array}{c}82(31.7) \\
23(8.9) \\
9(3.5) \\
4(1.5) \\
141(54.4)\end{array}$ & $\begin{array}{c}65(27.1) \\
9(3.8) \\
8(3.3) \\
5(2.1) \\
153(63.8)\end{array}$ \\
\hline $\begin{array}{l}\text { Incision } \\
\text { Cuts like a razor } \\
\text { Tearing the flesh } \\
\text { Not chosen }\end{array}$ & $\begin{array}{c}27(10.4) \\
6(2.3) \\
226(87.3)\end{array}$ & $\begin{array}{c}10(4.2) \\
10(4.2) \\
220(91.7)\end{array}$ \\
\hline $\begin{array}{l}\text { Compression } \\
\text { Like a pinch } \\
\text { Under pressure } \\
\text { Compression } \\
\text { Like a bite } \\
\text { In colic/cramp } \\
\text { That crushes } \\
\text { Not chosen }\end{array}$ & $\begin{array}{c}52(20.1) \\
16(6.2) \\
- \\
3(1.2) \\
13(5.0) \\
3(1.2) \\
172(66.4)\end{array}$ & $\begin{array}{c}42(17.5) \\
10(4.2) \\
- \\
2(0.8) \\
10(4.2) \\
2(0.8) \\
174(72.5)\end{array}$ \\
\hline $\begin{array}{l}\text { Traction } \\
\text { That stretches } \\
\text { That plucks } \\
\text { That splits in half } \\
\text { Not chosen }\end{array}$ & $\begin{array}{c}109(42.1) \\
2(0.8) \\
2(0.8) \\
146(56.4)\end{array}$ & $\begin{array}{c}89(37.1) \\
- \\
2(0.8) \\
149(62.1)\end{array}$ \\
\hline $\begin{array}{l}\text { Heat } \\
\text { That heats } \\
\text { That burns like hot water } \\
\text { That burns like fire } \\
\text { Not chosen }\end{array}$ & $\begin{array}{c}47(18.1) \\
13(5) \\
2(0.8) \\
197(71.6)\end{array}$ & $\begin{aligned} 29 & (12.1) \\
6 & (2.5) \\
5 & (2.1) \\
200 & (83.3)\end{aligned}$ \\
\hline $\begin{array}{l}\text { Vivacity } \\
\text { That scratches } \\
\text { In tingling } \\
\text { Burnt } \\
\text { Like a sting } \\
\text { Not chosen }\end{array}$ & $\begin{array}{c}12(4.6) \\
18(6.9) \\
55(21.2) \\
11(4.2) \\
163(62.9)\end{array}$ & $\begin{array}{c}9(3.8) \\
11(4.6) \\
58(24.2) \\
2(0.8) \\
160(66.7)\end{array}$ \\
\hline $\begin{array}{l}\text { Deafness } \\
\text { Dampened } \\
\text { Asleep } \\
\text { Not chosen }\end{array}$ & $\begin{array}{c}14(5.4) \\
8(3.1) \\
237(91.5)\end{array}$ & $\begin{array}{c}6(2.5) \\
9(3.8) \\
225(93.8)\end{array}$ \\
\hline $\begin{array}{l}\text { General } \\
\text { Sensitive } \\
\text { Sore } \\
\text { Like an injury } \\
\text { Heavy } \\
\text { Not chosen }\end{array}$ & $\begin{aligned} 59 & (22.8) \\
54 & (20.8) \\
40 & (15.4) \\
7 & (2.7) \\
99 & (38.2)\end{aligned}$ & $\begin{aligned} 56 & (23.3) \\
46 & (19.2) \\
31 & (12.9) \\
5 & (2.1) \\
102 & (42.5)\end{aligned}$ \\
\hline
\end{tabular}

Source: Database of the Research Project "Perineal conditions of women in vaginal postpartum in a public institution from the interior of Bahia," 2015. 
Table 2. Perineal pain characterization according to motivational-affective dimension's descriptors of the pain questionnaire (Br-MPQ) in women in vaginal postpartum with perineal trauma

\begin{tabular}{lcc}
\hline $\begin{array}{l}\text { Descriptors of } \\
\text { motivational-affective dimension }\end{array}$ & Episiotomy & Laceration \\
& $\mathrm{n}=259(\%)$ & $\mathrm{n}=240(\%)$ \\
\hline Fatigue & & \\
Tiring & $24(9.3)$ & $23(9.6)$ \\
Weakening & $14(5.4)$ & $13(5.4)$ \\
Exhausting & $6(2.3)$ & $1(0.4)$ \\
Consuming & $1(0.4)$ & $2(0.8)$ \\
Not chosen & $214(82.6)$ & $201(83.8)$ \\
Autonomy & & \\
Of cold sweating & $14(5.4)$ & $8(3.3)$ \\
Sickening & $2(0.8)$ & $6(2.5)$ \\
Not chosen & $243(93.8)$ & $226(94.2)$ \\
Fear & & \\
Scary & $9(3.8)$ & $7(2.9)$ \\
Horrible & $16(6.2)$ & $9(3.8)$ \\
Sinister & $1(0.4)$ & 0 \\
Not chosen & $233(90)$ & $224(93.3)$ \\
Punishment & & \\
Punishing & $35(13.5)$ & $13(5.4)$ \\
Excruciating & $7(2.7)$ & $6(2.5)$ \\
Stifling & 0 & $1(0.4)$ \\
Not chosen & $217(83.8)$ & $220(91.7)$ \\
Displeasure & & \\
Boring & $103(39.8)$ & $89(37.1)$ \\
Disturbing & $19(7.3)$ & $11(4.6)$ \\
That makes you nervous & $6(2.3)$ & $6(2.5)$ \\
Annoying & $12(4.6)$ & $5(2.1)$ \\
Of crying & $3(1.2)$ & $4(1.7)$ \\
Not chosen & $116(44.8)$ & $125(52.1)$ \\
\hline
\end{tabular}

Source: Database of the Research Project "Perineal conditions of women in vaginal postpartum in a public institution from the interior of Bahia," 2015.

Table 3. Perineal pain characterization according to cognitive-evaluative dimension's descriptors of the pain questionnaire (Br-MPQ) in women in vaginal postpartum with perineal trauma

\begin{tabular}{lcc}
\hline $\begin{array}{l}\text { Descriptors of } \\
\text { cognitive-evaluative dimension }\end{array}$ & $\begin{array}{c}\text { Episiotomy } \\
\mathrm{n}=259(\%)\end{array}$ & $\begin{array}{c}\text { Laceration } \\
\mathrm{n}=240(\%)\end{array}$ \\
\hline $\begin{array}{l}\text { Subjective evaluation } \\
\text { Mild }\end{array}$ & $82(31.7)$ & $72(30)$ \\
Uncomfortable & $97(37.6)$ & $80(33.3)$ \\
Miserable & $7(2.7)$ & $3(1.3)$ \\
Distressing & $6(2.3)$ & $7(2.9)$ \\
Unbearable & $1(0.4)$ & $2(0.8)$ \\
Not chosen & $66(25.6)$ & $76(31.7)$ \\
\hline
\end{tabular}

Source: Database of the Research Project "Perineal conditions of women in vaginal postpartum in a public institution from the interior of Bahia," 2015.

en with perineal laceration used the descriptors "that holds" (2.9\%) and "that immobilizes" (2.9\%) using, in sensory category, "that grows and decreases" (12.1\%); "cold" (7.1\%) in cold category; and "that makes me tense" (4.6\%) in emotional category.

\section{DISCUSSION}

It is known that in order to consider a descriptor of the Br-MPQ as a pain characteristic, it should be mentioned by at least $33 \%$ of the people surveyed ${ }^{9}$. Thus, only the descriptors with frequencies above this value are pain characteristics.
In this study, when comparing the characteristics of the perineal pain of the McGill questionnaire dimensions among women with episiotomy and laceration, the sensory-discriminative dimension was the most chosen. This result is consistent with the previous results from a study conducted with women in vaginal postpartum, most of them with perineum trauma, whose most used dimension to characterize the pain was sensory ${ }^{10}$.

Given that, since this dimension presents the sensorial qualities of pain", it is evident that both women with episiotomies and those with lacerations are more likely to report physical impressions on this symptom.

Still related to this dimension, for both traumas, more than half of the women chose the temporal and general categories. This shows that perineal pain presents a temporal variation, not characterized as constant pain, and the intensity of this pain is referred to in the general category?

This temporal characteristic of pain may be associated with the performance of physiological activities and needs, since sitting and urinating, for example, are difficult practices in the puerperium of women with perineal traumas due to the pain that is triggered or intensified during their performance ${ }^{11}$.

Although the temporal category was the most selected by the subjects in the sensory-discriminative dimension, the pain associated with episiotomy and laceration was also frequently characterized as "that stretches," from the traction category and this descriptor expresses a stretching sensation on the site?

The "displeasure" category was the most used in the motivational-affective dimension. This category expresses the suffering intensity that pain causes in the individual'. Both women with episiotomy and those with a perineal laceration, still in this category, used the "boring" descriptor to characterize their pain, which reveals the intensity of perineal pain and the unpleasant sensation associated with this discomfort.

More than half of the women with perineal trauma selected the cognitive-evaluative dimension. Such dimension analyzes the strength as well as the importance of the problem ${ }^{9}$, and this pain is more often described as "uncomfortable" by women with spontaneous or induced perineal traumas.

In the mixed dimension, the sensorial category prevailed, which refers to the sensorial-discriminative dimension. However, none of its descriptors characterized perineal pain, since there were no frequencies equal to or greater than $33 \%{ }^{9}$.

Although the inferential statistics were not used to analyze the perineal pain characterization, the data suggest that no differences were observed in the dimensions and selected categories as characteristics of perineal pain by women submitted to episiotomy and those with spontaneous lacerations. Thus, analyzing all the categories of the dimensions, the pain was characterized as "that stretches," "boring," and "uncomfortable," since only the frequencies of these descriptors were equal to or greater than $33 \%$.

The results of this study results partially corroborate the results of a descriptive study with 53 postpartum women, also comparing the pain characteristics among the traumas.

Women with episiotomies characterized pain predominantly as "uncomfortable" and "sore" and women who had perineal laceration as "sensitive" and "uncomfortable"12. 
A descriptive study carried out in São Paulo, Brazil, with 50 postpartum women, showed that perineal postpartum pain in women submitted to episiotomy was more characterized by the following $\mathrm{Br}$ MPQ descriptors: "throbbing," "that stretches," "that heats," "burnt," "sore," "boring," "uncomfortable," "that holds," and "that makes me tense," also partially corroborating the results of this study.

Similar to the previous study, another descriptive study developed with 40 primiparous postpartum women submitted to episiotomy found that the descriptors that best characterized the pain were: "sore," "that stretches," "uncomfortable," "boring," "burnt," "pricks like a needle" "throbbing," and "under pressure" 13.

Perineal pain may impact women's daily life after delivery, making it difficult or even impossible to perform basic activities, such as sitting, lying, walking, and compromising the performance of hygiene and urinary and intestinal eliminations ${ }^{9,14}$. A study carried out in a maternity hospital in the city of São Paulo showed that the pain reported by women submitted to episiotomy limited the execution of some habitual activities, mainly sitting, walking and sleeping. This same study found that the prevalence of perineal discomfort due to episiotomy is high, especially in the first 24 hours after delivery, a common complaint among many women after this period ${ }^{15}$.

However, despite this problem, the repercussions of perineal pain are low-valued by healthcare professionals, exposing women to unpleasant experiences in the postpartum period, which have repercussions on their organic recovery.

Thus, in this study, the characteristics of perineal pain according to the Br-MPQ were the same for women submitted to episiotomy and for those who presented spontaneous perineal lacerations. The sensory-discriminative dimension was the most reported by women with a perineal trauma of both types, with perineal pain being characterized as "that stretches," "boring," and "uncomfortable".

This study had some limitations. Because it is cross-sectional, its results cannot be generalized. Also, the Br-MPQ is extensive, and this may have led women to mark a few words or choose the first descriptors of the categories.

It is also worth mentioning the incipient production and publication of knowledge about the comparison of the pain characterization resulting from perineorrhaphy secondary to an episiotomy or spontaneous lacerations. Thus, the data from this study were limited to comparison with publications on episiotomy. Another limitation pointed out in this study was the absence of a comparison between episiotomy and non-sutured perineal lacerations.
Therefore, it is of fundamental importance to conduct new investigations on the subject, including women with lacerations that were not sutured and that have a multicentric character.

\section{CONCLUSION}

Perineal pain, characterized as "that stretches," "uncomfortable," and "boring," causes discomfort in women and can interfere with their well-being. Therefore, it is important that the episiotomy is performed in a restricted way and that the professionals use techniques of perineal protection since this can reduce the frequency of perineal pain and provide greater comfort to the woman in the immediate puerperium.

\section{REFERENCES}

1. Carmo Leal MD, Pereira AP, Domingues RM, Theme Filha MM, Dias MA, Nakamura-Pereira $\mathrm{M}$, et al. [Obstetric interventions during labor and childbirth in Brazilian low-risk women]. Cad Saúde Publica. 2014;30(Suppl 1):S1-16. English, Portuguese.

2. Francisco AA, Oliveira SM, Santos JO, Silva FM. Avaliação e tratamento da dor perineal no pós-parto vaginal. Acta Paul Enferm. 2011;24(1):94-100.

3. Silva NL, Oliveira SM, Silva FM, Santos JO. Dispareunia, dor perineal e cicatrizaçáo após episiotomia. Rev Enferm UERJ. 2013;21(2):216-20.

4. Figueiredo G, Barbieri M, Gabrielloni MC, Araújo ES, Henrique AJ. Episiotomy: perceptions from adolescent puerperae. Invest Educ Enferm. 2015;33(2):365-73. English, Portuguese.

5. Progianti JM, Araújo LM, Mouta RJ. Repercussốes da episiotomia sobre a sexualidade. Esc Anna Nery Rev Enferm. 2008;28;12(1):45-9.

6. Beleza AC, Ferreira CH, Sousa Ld, Nakano AM. [Measurement and characteristics of pain after episiotomy and its relationship with the activity limitations]. Rev Bras Enferm. 2012;65(2):264-8. Portuguese.

7. East CE, Sherburn M, Nagle C, Said J, Forster D. Perineal pain following childbirth: prevalence, effects on postnatal recovery and analgesia usage. Midwifery. 2012;28(1):93-7.

8. Pimenta CA, Teixeira MJ. Questionário de dor McGill: proposta de adaptação para a língua portuguesa. Rev Esc Enf USP. 1996;30(3):473-83.

9. Castro CES. A formulação linguística da dor: versăo brasileira do questionário McGill de dor [dissertação]. São Carlos (SP): Departamento de Fisioterapia, Universidade Federal de São Carlos; 1999.

10. Mathias AE, Pitangui AC, Vasconcelos AM, Silva SS, Rodrigues PS, Dias TG. Mensuraçáo da dor perineal no pós-parto vaginal imediato. Rev Dor. 2015;16(4):267-71.

11. Way S. A qualitative study exploring women's personal experiences of their perineum after childbirth: expectations, reality and returning to normality. Midwifery. 2012;28(5):712-9.

12. Almeida CB, Sé CC, Pereira, EG, Pereira, AL. Avaliação da dor decorrente da perineorrafia no parto normal. Rev Pesqui Cuid Fundam. 2011;3(3):2126-36

13. Pitangui AC, Sousa L, Ferreira CH, Gomes FA, Nakano AM. Mensuraçáo e características da dor perineal em primíparas submetidas à episiotomia. Acta Paul Enferm. 2009;22(1):77-82

14. Lopes DM, Bonfim AS, Sousa AG, Reis LS, Santos LM. Episiotomia: sentimentos e repercussóes vivenciadas pelas puérperas. Rev Pesqui Cuid Fundam. 2012;4(1):2623-35.

15. Francisco AA, Oliveira, SM, Silva FM, Santos JO, Leister N, Riesco ML. Efecto del dolor perineal en las actividades de mujeres sometidas a episiotomía. Index de Enfermería. 2012;21(3):150-4 